\title{
STATE CAPTURE: IS IT A CRIME? HOW THE WORLD PERCEIVED IT
}

\author{
Lily Evelina Sitorus ${ }^{1}$
}

\begin{abstract}
State capture has emerged as a global threat in several countries. The definitions vary from the act of rent-seeking to corruption. Russia, Ukraine, and some countries in Central Asia are several areas where state capture was first observed. Indonesia is not immune from the threat. Several misconducts in the country had already been labeled as state capture. There are some distinctions between state capture and corruption, whereas in a few countries both are considered as the same. Strategies for combating corruption usually involve reducing state capture.
\end{abstract}

\section{Introduction}

In common understanding, corruption is often referred to either as bribery practice or as major embezzlement/plundering of public monies. There is also a third form of corruption, less known but still very pervasive, found often but not exclusively in transition countries: state capture.

State capture has evolved from being contested as the lead factor in corruption in the Former Soviet Union in its early days of the discussion, to increasingly being re-examined with more scepticism as to its actual prevalence and its status as the leading type of corruption in the region.

\section{Definitions}

When we think about corruption, an image quickly comes to mind a bureaucrat extorting bribes from powerless individuals and defenceless firms simply to enable them to "get things done." Behind this view lies an understanding of the state extracting rents from the economy for the exclusive benefit of politicians and bureaucrats.

Joel Hellman and Daniel Kaufmann (2001) said that in transition economies, corruption has taken on a new image-that of so-called oligarchs manipulating policy formation and even shaping the emerging rules of the game to their own very substantial advantage. They refer to this behaviour as state capture. $^{2}$

'State capture' was also defined by Vesna Pesic (2007) as any group or social strata, external to the state, that seizes decisive influence over state institutions and policies for its own interests and against the public good. ${ }^{3}$

\footnotetext{
${ }^{1}$ The author currently works in the Directorate of Intellectual Property Rights, Ministry of Justice and Human Rights, Republic of Indonesia. The author welcomes all comments at lily_eve2001@yahoo. com

${ }^{2}$ Joel Hellman and Daniel Kaufmann (2001). Confronting the Challenge of State Capture in Transition Economies, Finance \& Development. Volume 38 Number 3 from http://www.imf.org/external/ pubs/ft/fandd/2001/09/hellman.htm

${ }^{3}$ Vesna Pesic (2007). State Capture and Widespread Corruption in Serbia. CEPS Working Document No. 262/March 2007 from http://www.ceps.eu/ceps/download/1309
} 
Teten Masduki, one of the major players for combating corruption in Indonesia also has a similar view that state capture is a policy made to the advantage of entrepreneurs. ${ }^{4}$

Anne Lugon-Moulin (2010) in understanding state capture said that it occurs when the ruling elite and/or powerful businessmen manipulate policy formation and influence the emerging rules of the game (including laws and economic regulations) to their own advantage. ${ }^{5}$

In recognising the problem of state capture, Helmann and Kaufmann put their effort on the complex interactions between firms and the state. Particularly, they emphasized the importance of mechanisms through which firms seek to shape decisions taken by the state to gain specific advantages, often through the imposition of anticompetitive barriers that generate highly concentrated gains to selected powerful firms at a significant social cost. Because such firms use their influence to block any policy reforms that might eliminate these advantages, state capture has become not merely a symptom but also a fundamental cause of poor governance. ${ }^{6}$

The dangers to the long-term development of such a capture economy are self-evident. New, dynamic entrepreneurs have strong incentives to invest their talents in capturing the state rather than in developing innovative products or production methods, in order to compete successfully in a distorted environment.

In a way, Helmann and Kaufmann said that the capture economy rewards connections over competence and influence over innovation; it is fuelled by private investments in politics that weaken the state and undermine the provision of basic public goods. At the same time, they also find that capture economy systematically deters private economic investments, both foreign and domestic, and creates obstacles to the entry of small- and medium-sized enterprises (SMEs), undermining the key sources of sustainable growth. ${ }^{7}$

In the absence of access to government decision making through collective representatives, firms are compelled to seek informal, one-on-one relationships with individual state officials to represent their interests. A number of key writings on the topic suggest the roots of state capture extend from partial civil liberties, lack of transparency, competition, and insecurity of property rights. The lack of transparency tends to go hand in hand with insufficient competition among firms and other constituencies to influence the state's deliberative processes. Fostering competition in the economy and in the marketplace for political influence is the main challenge in preventing and combating state capture. ${ }^{8}$

\section{Modes}

There are several modes of state capture present in every country. Even the definitions vary. The common understanding is that state capture and legal

\footnotetext{
${ }^{4}$ Lily Evelina Sitorus (2009). Release and Discharge sebagai Altenatif Penyelesaian Masalah (Studi Banding Kasus Kebijakan Penyelesaian BLBI). Tesis: FISIP UI.

${ }^{5}$ Anne Lugon-Moulin, Understanding State Capture. Freedom from Fear Magazine from http://www. freedomfromfearmagazine.org/index.php?option=com_content\&view=article\&id=233:understandingstate-capture $\&$ catid=49:issue- $6 \&$ Itemid $=161$

${ }^{6}$ Hellman and Kaufmann. Loc. Cit.

${ }^{7}$ Ibid.

${ }^{8}$ Ibid.
} 
corruption are one and the same. While most types of corruption are directed toward changing how existing laws, rules, or regulations are implemented with respect to the bribe payer, state capture refers to corrupt efforts to influence how those laws, rules, and regulations are formed. ${ }^{9}$

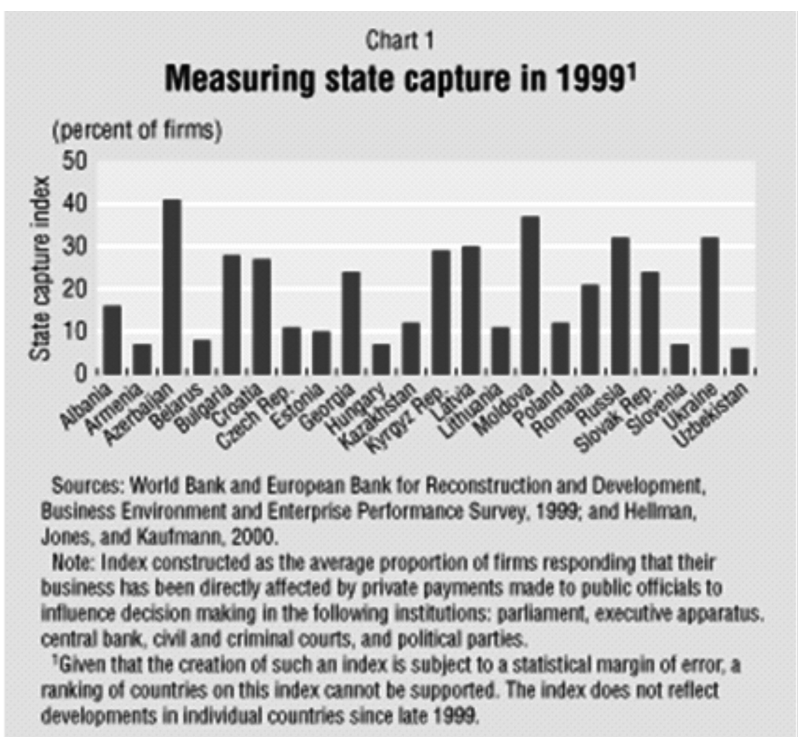

The high-capture group includes countries regarded as partial reformers in both political and economic terms. Although they have made progress in liberalisation and privatisation, they have been much slower to enact the complementary institutional reforms to support the emergence of markets.

State capture can be distinguished between types of institutions subject to capture (Legislative, Executive, Judiciary, regulatory agencies, or public works ministries) and the types of actors actively seeking to capture (large private firms, political leaders, high ranking officials, or interest groups).$^{10}$

Concentration of both economic and political power is also likely to lead to serious state capture, which usually goes hand in hand with a weak civil society, according to Helmann and Kaufmann. Bribes to parliamentarians to "buy" their votes on important pieces of legislation, bribes to government officials to enact favourable regulations or decrees, and bribes to judges to influence court decisions-these are the classic examples of grand corruption through which firms can encode advantages for themselves into the basic legal and regulatory structure of the economy.

In most transition economies, the mechanisms through which the state deliberates on the formation of laws, rules, and decrees are still largely hidden from public view. The use of public hearings and the Internet to provide a transparent forum for open decision making is rare. Draft laws are seldom published for discussion. Transcripts of deliberations are not available for public perusal. The voting records of individual legislators are not made available to the public.

\footnotetext{
${ }^{9}$ Ibid.

${ }^{10}$ Anne Lugon-Moulin. Loc. Cit.
} 
At the same time, the institutional tools that various constituencies can use to gain access to the state's deliberations are very limited. Political parties are weak. Trade associations, interest groups, and collective organisations lack the resources and experience to influence policy. ${ }^{11}$

Due to the fact, Helmann and Kaufmann saw few transition countries have sufficient safeguards to ensure proper disclosure of efforts to influence public officials, creating an environment highly susceptible to capture. Firms have little incentive to report their political contributions, and public officials face few or no real sanctions for accepting such contributions.

In that matter, periodic public declarations of assets and income sources by government officials (and at times by their dependents) are now required in many transition countries, but the relevant implementation mechanisms remain quite weak. Conflict-of-interest rules are poorly understood and barely enforced. Public interest watchdog groups have little capacity to monitor the flow of funds from firms to politicians.

Case to the point in Indonesia, even if the Ministry of Communication and Information had already released the proper legislation for public transparency, ${ }^{12}$ the implementation of it is hard to reach. When the mark up of police account happens, the party concerned based in this law asks for police transparency but it is usually rejected. ${ }^{13}$

Helmann and Kaufmann research found that in the capture economy, political influence is monopolised by powerful firms at different levels of government, with minimal checks and balances exerted by collective interests. In several transition countries, the monopolisation of political channels of influence reflects the underlying structure of the economy-in particular where the high concentration of natural resources in national output creates a highly unequal distribution of power across different firms and different sectors.

In other countries, such monopolisation reflects continued restrictions on the extent of political competition. The state-capture index is systematically lower in countries that have pursued more comprehensive economic reform. Furthermore, at any given pace of economic reform, there is a dramatic decline in state capture in countries with higher levels of civil liberties. Yet, it is clear that the causal links between capture and reform run in both directions, which makes breaking out of the vicious circle so difficult. ${ }^{14}$

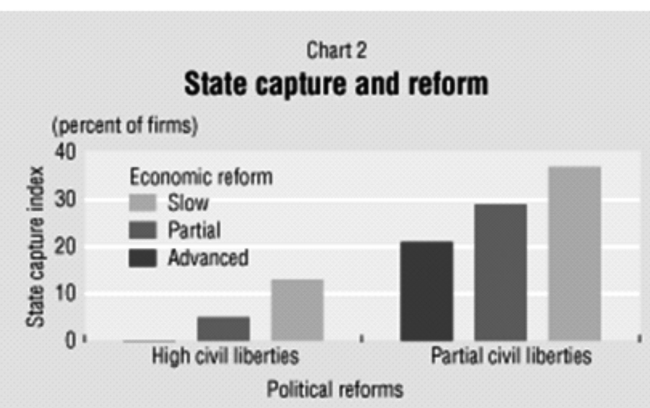

Sources: World Bank and European Bank for Reconstruction and Development, Business Environment and Enterprise Performance Survey, 1999, and Hellman, Jones, and Kaufmann, 2000.

Note: The chart represents the fitted values from a regression of state capture on economic and political reforms. Economic reform is measured as the average score on the 1999 European Bark for Reconstruction and Development transition indicators for each country in the sample, with countries grouped into slow, partial, and advanced reformers (as indicated in the legend above). Political reform is measured by the Freedom House index of civil liberties averaged over 1997-99, with countries grouped into those with high and partial civil liberties reforms. Countries designated "not free" in the Freedom House index are excluded.

\footnotetext{
${ }^{11}$ Hellman and Kaufmann. Loc. Cit.

${ }^{12}$ UU No 14 Tahun 2008 (Law Number 14 Year 2008).

${ }^{13}$ ICW Ajukan Sengketa Informasi soal Rekening Gendut Pati Polri (ICW asked for police account transparency) from http://antikorupsi.org/antikorupsi/?q=content/18862/icw-ajukan-sengketainformasi-soal-rekening-gendut-pati-polri

${ }^{14}$ Hellmann and Kaufmann. Loc. Cit.
} 
Anne Lugon-Moulin presented as example how captor firms can receive extra advantages not only in the form of sales increases, but also in the provision of public goods, such as property rights, by purchasing individualised protection of their property rights from the state. ${ }^{15}$

However, that comes at a significant social cost: if politicians and bureaucrats can minimise their political risks by selling privately such public goods to a few individual firms in exchange of economic revenues, they have little incentive to provide the public at large with open access to these goods. Therefore, the level of insecurity of property rights is much higher for the average firm and the ordinary citizen. Specific examples are state-owned enterprises sold at low prices to politicians and new laws designed in a way of favouring specific economic actors in a given sector at the expense of free and fair competition for all. ${ }^{16}$

\section{Practices}

The practices of state capture had invoked the party involved to find the solutions. Kaufmann is one of the leading researchers in these matters. His research basically made the basic ground for other researches to be held. World Bank and the European Bank for Reconstruction and Development (EBRD) conducted joint initiative to form The Business Environment and Enterprise Performance Survey (BEEPS). ${ }^{17}$

The results of the survey in 2002 showed that there has been a decline in state capture--significant in some cases--across the transition countries. The countries where capture was most pronounced--Russia, Ukraine, Azerbaijan, and Moldova-have seen the sharpest decline, while countries with more modest capture levels, for example in some south-eastern European countries, have remained more or less constant or have experienced an increase in levels of capture. ${ }^{18}$

\section{Russia ${ }^{19}$}

Practitioners in Russia consistently highlight two parallel processes taking place in the country: state capture and business capture (the latter being used to describe the state unlawfully taking control and exercising undue influence over businesses); or even, as described by some, these two processes have been turned into the fusion of state + business by the elite, with former bureaucrats running businesses and business leaders holding or controlling political office.

Amongst the key measures to address the situation are the introduction of conflict of interest regulations, codes of conduct, and wide-ranging transparency reforms. In addition, it has now been acknowledged by many that to galvanise Russia's public debate over corruption, it is vital to remove the sole responsibility for reform from the government. By focusing on the supply-side, debate can lead to more direct, immediate and measurable action, particularly in areas like state capture. Thus, the importance of engaging the business community in the process is being increasingly highlighted.

\footnotetext{
${ }^{15}$ Anne Lugon-Moulin. Loc. Cit.

${ }^{16}$ Ibid.

${ }^{17} \mathrm{http}: / /$ www.ebrd.com/pages/research/analysis/surveys/beeps.shtml

${ }^{18}$ Donals Bowser. Addressing State Capture in Russia/Ukraine/Central Asia. Anti-Corruption Resource Center from http://www.u4.no/helpdesk/helpdesk/queries/query18.cfm ${ }^{19}$ Ibid.
} 


\section{a. Engaging The Business Community: Collective Action, Business Self-Regulation, Etc.}

Earlier this year, Russian President Vladimir Putin publicly challenged the leaders of the Union of Industrialists and Entrepreneurs (RSPP) to help "destroy the breeding ground for corruption." RSPP is a business association that includes the financial-industrial groups that secured control of a majority of the country's wealth during the past decade of privatisation. The association responded by creating a working group that will recommend administrative reform measures to the president, which will include reducing obstacles to any business that provides the opportunity and incentive to engage in various forms of corruption, including state capture.

Notwithstanding the fact that civil servants play a role in both state and business capture, the breeding ground can be attacked only if private sector leaders take initiative. There are numerous market incentives for RSPP and other business leaders to adopt anti-corruption practices. Those include enhancing reputation and good will as business assets, reducing the risk and costs associated with capture, strengthening competitive position, increasing shareholder value, and gaining access to capital and credit on better terms. In the long-term, RSPP requires institutions that can govern a market economy built on true competition. To meet Putin's challenge, RSPP should take concrete initiatives that can be implemented largely by the supply side. In particular, RSPP members should form "integrity pacts" with other large businesses, SMEs, and non-governmental organisations (NGOs) at the national and regional levels designed to institute conditions for transparent and fair business competition.

The most concrete form of an integrity pact is a "no-bribery pledge," under which companies entering a government tender or privatisation bid and the officials responsible for choosing the winner commit to a transparent procedure. In particular, they pledge not to offer, pay, accept, or seek bribes of any kind during the tender. To show their good faith, they may place funds in escrow that they would relinquish if they did engage in bribery. If a business does not abide by the guidelines, it will lose the bid and other participants in the pledge can stop doing business with (or blacklist) it. Such pacts have been implemented to one degree or another throughout the world. To maximise impact on economic growth, RSPP should form integrity pacts that help both large enterprises and SMEs.

RSPP leaders should also take initiative in regions where they operate their factories and other outlets. They are in the best position to help institute local programmes to monitor government agencies and budget processes, increase access to information regarding allocation of public resources, and foster independent oversight of public procurement. These are best done through joint coalitions with NGOs and watchdogs.

RSPP is not the only institution engaging in the process of private sectordriven initiatives to address corruption and state capture. Disproportionately injured by the extortion practices of officials at all levels, SMEs are already taking local initiatives throughout Russia. Another example of a private sector initiative is the formation---by a highly regarded economics professor, Lev Kaplan, and the General Director of the U.S. subsidiary of Otis Elevator, Vladimir Marov--of 
an "Honest Builders' Club." The coalition dedicated to fair business practices now includes 30 of the largest local construction companies, various NGOs, and the city's Vice-Governor for Construction.

The Association of Minority Shareholders' Rights assisted the Kremlin's efforts to expose shady financial deals at Gazprom, 38 percent of which is owned by the state. Minority shareholders claimed that the theft of vast amounts of cash had kept share prices low and reduced profits. In December 2001, Gazprom's new management decided to reclaim the Purgaz gas field, a valuable asset that was previously 'pawned.' Since the new management arrived, Gazprom shares have risen 44 percent.

The Corporate Behavioural Code is one example of Russia's determination to improve corporate governance and the investment climate. More than 150 Russian companies were consulted in the course of developing the code. It includes amendments to the joint stock company law, securities market law, the criminal law, and provisions of criminal liability in cases of non-disclosure, as well as measures for enforcement. While some are skeptical as to the genuine intentions, it is widely expected to seal major loopholes in existing corporate governance structures.

\section{b. Transparency Measures ${ }^{20}$}

Among recent concrete measures and/or developments aimed at improving transparency are:

\section{On elections, Party Finance, and Lobbying Regulations}

Russia passed a law on the election of deputies to the State Duma in November 2002. While the basic provisions of the law remain the same as in the 1999 version, it contains some new provisions concerned with finance, namely the introduction of spending caps, stricter regulation of funding sources, and size of acceptable donations. A law on the presidential election was passed in December 2002 with the intention to streamline a hitherto complicated process.

Party financing and regulations remain as major issues for Russia in the context of state capture. Informal political actors--financial groups and political "oligarchs"--dominate the political spectrum. Political parties are included into the structure of an "oligarchy" to act as legitimate vehicle for engagement in public policy and lobbying. They are supported by their own controlled mass media and key industries.

\section{On access to Information}

Russia's federal access to information law has not yet passed the stage of parliamentary debate and is under review by the Duma since 1996 . Some regions and local entities (including Kaliningrad, Greater Novgorod) have, however, engaged in reform with the goal of making information held by government bodies available to the general public. Generally speaking, access to information is not considered a great priority by politicians and the civil society alike in a context in which the state is still largely perceived to be a ruler, rather than a provider of public services.

\footnotetext{
${ }^{20}$ Ibid.
} 


\section{Ukraine}

In Ukraine, the dominant motive appears to be revenge against the oligarchs who supported the old regime. Big businessmen identified with the new regime may also have their own motives in seizing the assets of the old oligarchs. Again, a third goal is to level the playing field. Clearly, the two first objectives contradict the third one, which is the legitimate goal. One idea is that the privatisation will be annulled, compensation will be paid to the prior owner for his initial payment, and then the enterprise will be sold anew by the state at a competitive auction. The redistribution of property is often considered as one of the characteristics of a revolution. ${ }^{21}$

\section{On elections, Party Finance, and Lobbying Regulations ${ }^{22}$}

Ukraine has adopted a number of laws to regulate this area, among them the 2001 Law on Political Parties, the 1999 Presidential Election Law, and the 2001 Parliamentary Election Law. The latter is considered to be an improvement compared to the previous (1998/94) legislations.

Ukraine has introduced some specific measures on public disclosure of political finances, such as for example, the information on the size and sources of contributions to the funds of candidates, as well as publication of financial statements indicating the use of those funds. The CEC (the central electoral body) has to publish the information in two national newspapers within seven days prior to the elections.

One of the most severe problems in the area of elections, campaign financing, and regulation that has direct impact on the dynamics of state capture is still the issue of funding sources for political parties. Ukrainian fragmented and non-institutionalised party system keeps encouraging big businesses to form client circles and run their own parties to directly control decision-making processes.

In terms of Civil Society-led concrete initiatives in this area, Transparency International (TI) national chapter (and "Freedom of Choice Coalition") had implemented a project on Public Monitoring of Parliamentary Electoral Campaign Financing in 2002.

\section{Central Asia ${ }^{23}$}

State capture does not necessarily remain stable over time. In many instances, efforts were focused at constructing well-functioning states early in the transition period only to be swamped in the second half of the decade. For some countries, it is a question of whether they will progress or regress in the transition to democracy and to a market economy. In Central Asia, Kazakhstan is one of the examples.

\section{On elections, Party Finance, and Lobbying Regulations}

Kazakhstan adopted a Law on Political Parties on 26 June 2002. It introduced fundamental changes to the financial activities of political parties,

${ }^{21}$ Anders Aslund (2005). Comparative Oligarchy: Russia, Ukraine and the United States. Center for Social and Economic Research from http://www.case.com.pl/upload/publikacja_plik/4931074_ SA\%20296last.pdf

${ }^{22}$ Bowser. Loc. Cit.

${ }^{23}$ Ibid. 
including their sources of funding. Potential transparency and accountability gains are, however, contravened by the inclusion of clauses in the law that in turn directly affects the formation and operation of political parties, e.g. the requirement of a minimum 50,000-membership for a party to register and the introduction of mechanisms designed to enable the state to interfere in the internal affairs of political parties.

\section{On Access to Information}

In Kazakhstan, the Constitution of the Republic of Kazakhstan (adopted in 1995) guarantees access to information as a constitutional right: Everyone shall have the right to freely receive and disseminate information by any means not prohibited by law. The list of items constituting state secrets of the Republic of Kazakhstan shall be determined by the law. The subsequent law, however, "on protection of state secrets of the Republic of Kazakhstan," which "determines legal principles and the single system of protection of state secrets in all types of activity of state executive and management agencies, enterprises, institutions, associations, and organisations, irrespective of the form of property, as well as of military units and citizens of the Republic of Kazakhstan on the territory of the state and outside of it," is rather extensive.

The Kyrgyz Republic adopted a Law on the Fight against Corruption on 6 March 2003. Other than establishing the legal and organisational foundations for the fight against corruption in Kyrgyzstan, the law explicitly mentions the role of the media in investigating corruption offences and disseminating information regarding the latter. It also establishes provisions for government agencies to publicise information relating to internal corruption matters.

\section{On Conflicts of Interest and Disclosure}

The term "conflicts of interest" did for the first time become a provision of Kazakhstan's law on control over execution of national and local budgets enacted in 2002. It is provided for as any activity of relations which is capable of limiting the objectivity and the independence of the state body employees in terms of either internal or external control.

A Kazakh governmental decree of 2000 establishes that all civil servants within a month of assuming office are obliged for the duration of their public service to transfer to confidential management any shares of participation in authorised capital of commercial organisations and other conflicting property and assets. Kyrgyzstan does not have any specific conflict of interest legislation, but interestingly it is regulated as an aspect of corruption by the standards of the Criminal Code.

Finally, an interesting governmental body is under discussion for establishment in Kyrgyzstan-the National Council on Faithful Management. Its main tasks are inter alia to include taking steps to eliminate the unwarranted and needless interference of the state structures into the economy and commercial entities.

\section{State Capture in Indonesia}

Taking the role as Putin already had is Indonesian President Susilo Bambang Yudhoyono. When elected as the sixth president of the country, he 
introduced the integrity pact for his cabinet. Candidates for any ministry office must sign their commitment to avoid corruption according to the code of conduct. ${ }^{24}$ This action might relate to the history of Indonesia under the Suharto regime.

The Suharto government may have never intended to give grief to Indonesia, but alas after ruling for almost 32 years, it had established itself as a corrupt regime. After that, Indonesia forced to embark on a comprehensive and unprecedented process of decentralisation, devolving--almost overnight-enormous responsibilities to regional, provincial, and local governments. In spite of considerable achievements, the Indonesian decentralisation process continues to face major challenges of state capture by the local elites, a deeply entrenched patronage system, and widespread petty and bureaucratic corruption.

The greater the achievement, the greater the risk involved. The emergence of stronger civil society and a free media constitute promising trends that combined with further reforms aimed at promoting transparency and community participation, as well as reinforcing upward and downward accountability mechanisms. It could ensure that decentralisation fully yields the intended benefits.

TI in accordance with Anti Corruption Resource Centre ${ }^{25}$ tries to fully understand the nature of corruption challenges at the local level. In query, they said that it is important to analyse the successes and failures of Indonesia' s unprecedented decentralisation process, that transferred rapidly complete responsibility for most public services to the sub national level. The fast transition from a highly centralised to a largely decentralised system has created specific accountability challenges that significantly affect corruption risks at the local level.

\section{Definitions}

Todung Mulya Lubis (2009), senior advocate practising in Indonesia, said that Lapindo's mud case in Sidoarjo is an example of state capture corruption. An activist for Transparency International Indonesia (TII), Lubis surely knows enough about corruption practices. He said that the Lapindo case is a manifestation of state capture corruption.

Furthermore, in media ${ }^{26}$ he explained that state capture corruption happens if there are some parties that may gain benefits from government policy. Indication to the fact can be seen in this case when the party involved never took the responsibility for the disaster. The policy endorsed by Indonesian government to take responsibility for Lapindo mud flow victims has illustrated how businesses may shift a policy against public interests.

What makes state capture possible according to David Kupferschmidt (2010) from International IDEA is the existence of a well-organised and a well-funded interest; in the case of Indonesia, the powerful business groups. Their control of large media groups, combined with weak law enforcement,

\footnotetext{
${ }^{24}$ Calon Menteri harus tanda tangani komitmen anti-korupsi (2009). Antaranews.com from http:// www.antaranews.com/berita/1255836656/calon-menteri-tanda-tangan-anti-korupsi

${ }^{25}$ Marie Chene (2009). Corruption Challenges at Sub-National Level in Indonesia. Anti-Corruption Resources Center from http://www.u4.no/helpdesk/helpdesk/query.cfm?id=210

${ }^{26}$ Todung: Kasus Lapindo adalah "state capture corruption (2009). Antaranews.com from http:// www.antaranews.com/berita/1251382626/todung-kasus-lapindo-adalah-state-capture-corruption
} 
contributes to establishment of a conducive environment to state capture. ${ }^{27}$

State capture can be described as "investment" in political parties through political financing or bribery in law enforcement agencies, combined with the utilisation of mass media to influence public opinion and policy making. It allows powerful interest groups to use their abundant financial resources to halt the opportunities for gaining economic, legal, and social benefits. ${ }^{28}$

Colombian economist Luis Jorge Garay, under the concept of Co-opted State Reconfiguration, asserted that the action of legal and illegal organisations, through illegitimate practices, seek to systematically modify from within the political regime and influence the formation, modification, interpretation, and application of the rules of the game and public policies. These practices are undertaken with the purpose of obtaining sustained benefits and ensuring that their interests are validated politically and legally, as well as gaining social legitimacy in the long run, although these interests do not follow the founding principle of social welfare". ${ }^{29}$

The Corruption Eradication Commission (KPK), which has been under constant attack from the police, the attorney-general office, and parliament members for the last couple of years, remains as one of the last rampant against the impunity sought by state capturers. The Indonesian political party system is characterised by a growing individualisation of weak leadership and by the inability of political parties to identify the champion core of constituent groups and to articulate policy programs.

The reality of Indonesia's politics is that liberalised elections are extremely costly for political parties. In a country with enormous and demographically heterogeneous characteristics, winning elections requires both securing access to financial resources, and strengthening the presence and visibility of political parties at the local level to mobilise voters. Incumbent leaders clearly have a competitive advantage on both fronts due to their influence on local budgets, their ability to help businesses with close ties to political parties, and their ability to use state resources to build strong support bases, particularly through the allocation of social funds to mass organisations. ${ }^{30}$

In its press release, TII concluded that the financing of local elections is the root of political corruption and state capture at the regional level. Besides its direct impact on state resources, it raises more fundamental issues related to political leadership, the strengthening of Indonesia's political party system, and public trust towards democracy.

Soekarno, the Founding Father of Indonesia had already addressed this issue in BPUPKI on 1 June 1945, "We are building a Nation for all. Not for one person, not for one class, not for aristocrats, nor for the rich, but for all." This cannot happen if the electoral process is rigged by money politics. One of the biggest challenges associated with decentralisation is the risk of state capture by the local elite.

With decentralisation, local elite and politicians suddenly gain access to regional resources they can divert to benefit influential groups and individuals whose money or votes count rather than the public at large. When

\footnotetext{
${ }^{27}$ Money Politics and State Capture (2010). Transparency International Indonesia from http:// www.ti.or.id/en/index.php/press-release/2010/11/11/money-politics-and-state-capture

${ }^{28}$ Ibid.

${ }^{29}$ Ibid.

${ }^{30}$ Ibid.
} 
civil participation in local government is low, as it seems to be the case in most Indonesian provinces, ${ }^{31}$ there is a greater chance of interest groups and local elite capturing and directing resources towards their own priorities rather than towards poverty alleviation and improved service delivery.

\section{Modes}

There are several types of state capture in Indonesia: ${ }^{32}$

\section{Local networks of Patronage}

Across the country, the various powers of the state tend to be concentrated in the village elites who usually maintain close and personal relations, increasing the risks of collusion between key stakeholders to pursue vested interests. This overlap of social and political functions and relations at the local level affects public- and private-sector hiring practices, business relationships, and awarding of contracts with widespread practices of nepotism and cronyism.

\section{Red tape and bribe extortion}

High level of bureaucracy provides multiple opportunities for rent-seeking at sub national level, with involved public officials having large discretionary powers as well as monopoly over these procedures. Bribes paid by firms mostly arise from red tape, particularly in permits and licenses imposed by local government officials. Research indicated that red tape and bribe extortion tend to decrease in better funded localities and with increased education of local officials. $^{33}$

\section{Lack of local capacity}

Corruption risks are further increased by the lack of capacity of local governments to manage increased responsibility and powers. Local governments often lack the human and material resources to perform government duties in a transparent and accountable manner as well as the operational and economic capacity to run competitive and efficient public services.

\section{Misuse of local public resources}

In many local regions, levels of local corruption strongly affect the efficiency of public spending on service delivery and the enactment of inconsistent local regulations governing local budgets by national and regional parliaments. Those can be magnified with the lack of local capacity to review budget documents and to monitor budget formulation and execution. Such have opened many opportunities for corruption and misuse of public resources. ${ }^{34}$

\section{Public procurement}

Local procurement is another area especially vulnerable to corruption due to the persistent culture of favours and patronage at the local level. As a result,

\footnotetext{
${ }^{31}$ Chene. Loc. Cit.

${ }^{32}$ Ibid.

${ }^{33}$ J. Vernon Henderson and Ari Kuncoro (2004). Corruption in Indonesia. Brown University from http://www.pstc.brown.edu/henderson-kuncoro.pdf

${ }^{34}$ Daniel Suryadarma (2008). Corruption, Public Spending, and Education Outcomes: Evidence from Indonesia Research School of Social Sciences The Australian National University.
} 
local procurement offers many opportunities for corrupt practices, including collusion of suppliers, bid-rigging, bribes and kickbacks, and favouritism in contracts' awarding.

\section{Facilitation and other informal payments}

Informal payments remain highly pervasive in the post Suharto era, including payments to speed up the issuance of certificates, permits, and licenses or to access public services that are supposed to be free of charge. Cutting across all sectors of service delivery, there are also opportunities for extorting money for so-called "services" such as school or hospital admissions, shoes or school uniforms (that are sold by the teachers), private tutoring, or bribes for good grades.

\section{Lack of efficient controls and oversight mechanisms}

In the urge to move away from the old autocratic regime, reforms failed to establish effective monitoring and evaluation mechanisms that can hold local governments accountable to the central government. Currently existing public mechanisms have not proven to be the most effective to uncover corruption cases in Indonesia. A World Bank study of 10 corruption cases in five Indonesian provinces shows that almost without exception, all corruption cases had been uncovered and reported by NGOs, community groups, social activists, individual villagers, or affected parties rather than oversight, audit, or justice institutions. ${ }^{35}$

\section{Culture of impunity}

Indonesia's long tradition of authoritarian rule has left a legacy of impunity for perpetrators of corruption, which combined with weak protection of whistleblowers; This provides fertile ground for rent-seeking behaviours. Sanctions have been rarely enforced, which tends to make corruption a lowcost and high-benefit activity, with little likelihood of redress. The traditional hierarchical structure of local villages also limits the propensity of citizens to question those in power. In addition, at the village level, citizens appear to have little awareness of their rights and entitlements, as well as of legal processes and resources. ${ }^{36}$

\section{Lesson Learned}

Corruption is a political problem that will require strong political commitment. It cannot be solely resolved with institutional reform. Additional efforts and resources should be directed to strengthen political accountability. Thus, by empowering civil society and constituency groups to demand accountability, we can earn a public policy that does not benefit vested interests at the expense of public interests and people's welfare.

\footnotetext{
${ }^{35}$ Taufik Rinaldi, Marini Purnomo and Dewi Damayanti (2007). Fighting Corruption in Decentralized Indonesia Case Studies on Handling Local Government Corruption from http://siteresources.worldbank. org/INTINDONESIA/Resources/Publication/corruption_exec_sum_en.pdf

${ }^{36}$ Andrea Woodhouse (2005). Village Corruption in Indonesia Fighting Corruption in Indonesia's Kecamatan Development Program. Indonesian Social Development Paper No. 6.
} 
The international development community has an important role in supporting the development of a strong and critical civil society. Many countries began transition as weak states unable to provide basic public goods and with sets of powerful incumbent firms (these were predominantly state owned and newly privatised) dominating their respective markets without having to resort to bribery payments.

To compete in such an environment, new entrants adopted a strategy of state capture to buy greater security for their property rights from public officials and to encode, or incorporate, competitive advantages into the emerging legal and regulatory framework. Thus, state capture became a strategy for a few firms to create zones of relative security and advantage for themselves at the expense of all other firms.

In high-capture economies, captor firms grow more than twice as fast as other firms. In sharp contrast, captor firms appear to enjoy few advantages in lowcapture economies, where such grand corruption looks more like a survival strategy for poorly performing firms. ${ }^{37}$

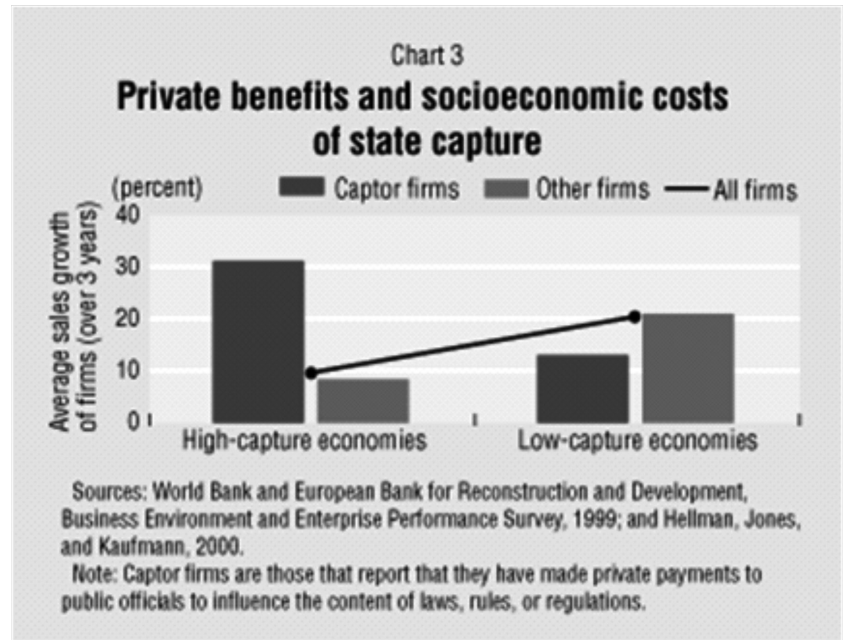

Transparent governance reforms are therefore highly needed to better share the power in the society, both horizontally and vertically, and to put in place very clear conflict of interests rules. State institutions should have safeguards to prevent them from being "owned" by specific individuals enjoying a high discretionary power. ${ }^{38}$

On the other hand, a vocal civil society, provided that basic civil liberties are ensured, will point at governance deficiencies, call for better accountability, and responsiveness from the side of the government. New incentives ought to be found to possibly instil a behaviour change in those actors.

International pressure or reward (such as joining the European Union) can be a very powerful tool, as demonstrated in the case of the new EU member states, which have undertaken major and rapid endeavours in the realm of governance to reach the goal of entering the EU. ${ }^{39}$

The efforts of firms to influence the legal, policy, and regulatory environment wherein they operate constitute a normal and indeed healthy process that is common to all countries. What distinguishes such interactions in the capture economy is exclusion. Some firms enjoy exclusive privileges

\footnotetext{
${ }^{37}$ Hellman and Kaufmann. Loc. Cit.

${ }^{38}$ Anne Lugon-Moulin. Loc. Cit.

${ }^{39}$ Ibid.
} 
to influence decisions of the state while others are systematically excluded, enabling state officials to make choices that concentrate benefits on those with access at a high cost to those who are excluded.

Although the general remedies for such problems-transparency and competition-are, by now, increasingly acknowledged, the specific ways in which reform of state capture can be achieved are less obvious. Mobilising the losers in the capture economy-small and medium-sized enterprises, consumers, and other interest groups-and enhancing their collective voice to counterbalance the captors can have a catalytic effect in weakening the foundation of the capture economy. ${ }^{40}$

An important reform instrument that is increasingly used by the more competitive sectors, the disenfranchised, non-governmental organisations, and others working to combat state capture is the power of data. Furthermore, policies that encourage market entry, which might be overlooked by the existing captors, are particularly important. Over time, more and more "smaller oligarchs" may emerge to compete for influence and dissipate the rents for state capture.

\section{Corruption As Crime}

"The cartels have not yet corrupted the government's senior levels, but sooner or later they will, because they have millions of dollars and you need to be a saint to reject them." ${ }^{\prime 1}$ Since time, both legitimate and illegitimate businesses have been attempting to distort or displace the state for its own gain. In many contexts, organised criminal groups have become major contenders in these efforts, engaging significantly at the intellectual, political, and institutional level with state and social actors.

Until recently, organised criminal activity was constrained within a state's borders or limited to a small number of global cartels and mafia groups. However, the end of Communism coupled with the expansion of global markets and the rising sophistication of information communications technology have spurred mass expansion of organised crime.

In the course of expanding their operations, transnational organised crime groups and networks have sought to gradually weaken, co-opt, disable, privatise, or usurp the functions of governmental agencies, political and judicial institutions, and the state itself. In contrast to other illicit means of interaction with the state such as 'influence' or 'administrative corruption,' organised criminal groups often seek to "prevent the law from being enforced altogether" leading to, or further ensconcing a culture of impunity.

In many states across the globe, politicians and public officials are perceived (and have often been found to be) as part of illicit, elite, and corrupt networks. Over time, this has resulted in increasing public mistrust of parliamentarians, public servants, and state institutions, often leading to a waning respect for authority and the rule of law, and decreased institutional legitimacy.

Despite the vast body of literature on these issues and the huge sums of money invested in developing policy and operational responses to meet the challenges that organised criminals and corrupt politicians and other state actors pose, significant challenges remain.

${ }^{40}$ Hellman and Kaufmann. Loc. Cit.

${ }^{41}$ Center on International Cooperation (2011). Seminar on Organized Crime and State Capture, Meeting Report. New York University from http://www.cic.nyu.edu/peacebuilding/docs/Lima\%20Semin ar\%20Background\%20Paper.pdf 
During the 1990s, law enforcement agencies in Europe developed a number of operational definitions of the phrase "organised criminal group." Those definitions agree on the following crucial elements: such a group is structured, has some permanence, commits serious crimes for profit, uses violence, has corrupt officials, launders criminal proceeds, and reinvests in the licit economy. ${ }^{42}$

While state capture is often practiced by private actors, it also can be practiced by people within the government, in alliance with private actors or not. Illicit political finance facilitates corruption and other means of effectively privatising - through bribes, intimidation, and violence - vital state functions, federal and local agencies, members of parliament, political parties, key government actors, local governments, and state territory. ${ }^{43}$

State capture aims at systematically distorting or displacing the state through a clandestine parallel entity or entities, and may be classified as the most pernicious manifestation of political corruption. State capture is to be distinguished from petty corruption; it is manifested as meta-corruption, or grand corruption, in which illicit political finance is used to systematically control public institutions.

While the phenomenon of state capture also takes place within nondemocratic governments, it can be argued that, except in rare cases, non-democratic governments are examples of comprehensive state capture, whether by clans, organised crime networks, armies, militias, liberation movements, oligarchs, multinational corporations, foreign governments, or a combination thereof.

Crime and corruption do not always co-exist, share the same determinants, or respond to the same strategies and measures. A corrupt and authoritarian police state can control common crime, as in North Korea. Conversely, common crime can be a challenge to countries with satisfactory anti-corruption track records, like Chile. ${ }^{44}$

Crime rates tend to be higher where there is high unemployment, high socio-economic inequality, and lax gun laws. Corruption thrives where civil liberties, free press, transparency, and contestable politics are absent. Functioning rule-of-law matters for controlling both crime and corruption; but again differences emerge: an independent judiciary is crucial for combating political corruption and an effective police is important for fighting petty corruption as well as common crime.

There are also differences between the determinants of common and organised crime, since the latter does relate to corruption more closely-for instance, drug traffickers and underground arms dealers thrive in collusion with corrupt authorities in weak states. Unfortunately, most of the research on corruption focuses on developing countries. When corruption indices measure cruder forms of corruption, such as bribery, they mask one of the most serious governance challenges facing countries like the United States today-so-called legal corruption and state capture by powerful corporations.

\footnotetext{
${ }^{42}$ Edgardo Buscaglia and Jan van Dijk (2003). Controlling Organized Crime and Corruption in the Public Sector. Forum on Crime and Society Vol 3 No. 1 and 2 from http://www.unodc.org/pdf/crime/ forum/forum3_Art1.pdf

${ }^{43}$ David Kupferschmidt (2009). Illicit Political Finance and State Capture. International IDEA from http://www.idea.int/resources/analysis/upload/IDEA_Inlaga_low.pdf

${ }^{44}$ Daniel Kaufmann (2010), Breaking the Cycle of Crime and Corruption? Brookings from http:// www.brookings.edu/opinions/2010/0414_corruption_crime_kaufmann.aspx
} 
The strategies to combat different manifestations of crime and corruption will differ from each other, and must be tailored to country context. To combat common crime, it is important to focus on shared socio-economic progress and reduced unemployment among the youth, police effectiveness, and effectivegun banamong civilians. To address legal corruption and state capture, reforms in transparency, as well as restrictions on corporate political finance and lobbying is needed.

Yet crime and corruption do share important aspects in common. To be prepared to take on powerful vested interests and to address the challenges of money in politics, political will, leadership, and integrity are required at the top. Some examples of strategic uses of illicit political finance used toward state capture are cursorily outlined in the following, as yet crude and tentative, table. ${ }^{45}$

\begin{tabular}{|c|c|c|c|c|}
\hline $\begin{array}{l}\text { Country/ } \\
\text { region }\end{array}$ & $\begin{array}{l}\text { Alleged agent(s) of } \\
\text { state capture }\end{array}$ & $\begin{array}{l}\text { Primacy source(s) of } \\
\text { illicit political finance }\end{array}$ & $\begin{array}{l}\text { Primary institutional } \\
\text { targets }\end{array}$ & $\begin{array}{l}\text { Territorial expression } \\
\text { of state capture }\end{array}$ \\
\hline Afghanistan & 'Warlords' & Poppies, heroin & $\begin{array}{l}\text { Politicians, army, border } \\
\text { control }\end{array}$ & Regional \\
\hline Bulgaria & $\begin{array}{l}\text { 'Organised crime' } \\
\text { consisting of former } \\
\text { and } \\
\text { current state security } \\
\text { agents }\end{array}$ & $\begin{array}{l}\text { Opaquely-privatised } \\
\text { industries, trafficking } \\
\pm \text { (of women), taxes }\end{array}$ & $\begin{array}{l}\text { Key institutions: customs, } \\
\text { judiciary, media, etc. }\end{array}$ & National \\
\hline Burma & Army & $\begin{array}{l}\text { Drugs, industries } \\
\text { controlled by army }\end{array}$ & The state & National \\
\hline Colombia & $\begin{array}{l}\text { Drug cartels, } \\
\text { guerrillas (ELN, } \\
\text { FARC), Paramilitary } \\
\text { Organisations }\end{array}$ & Drugs & $\begin{array}{l}\text { Legislature, political } \\
\text { parties, judiciary, police, } \\
\text { border }\end{array}$ & $\begin{array}{l}\text { Local control, with FARC } \\
\text { increasingly pushed into } \\
\text { remote areas }\end{array}$ \\
\hline Guatemala & $\begin{array}{l}\text { Elements of the Army } \\
\text { and } \\
\text { former secret services }\end{array}$ & Cocaine & $\begin{array}{l}\text { Institutions that might } \\
\text { impinge on or facilitate } \\
\text { trafficking }\end{array}$ & National \\
\hline $\begin{array}{l}\text { Guinea- } \\
\text { Bissau }\end{array}$ & Drug traffickers & Cocaine, foreign aid & $\begin{array}{l}\text { Institutions that might } \\
\text { impinge on or facilitate } \\
\text { drug trafficking }\end{array}$ & National \\
\hline $\begin{array}{l}\text { High-conflict } \\
\text { countries in } \\
\text { Sub-Saharan } \\
\text { Africa }\end{array}$ & $\begin{array}{l}\text { Armies (domestic and } \\
\text { foreign), 'rebel groups' } \\
\text { (domestic and foreign), } \\
\text { foreign corporations } \\
\text { exploiting natural } \\
\text { resources }\end{array}$ & $\begin{array}{l}\text { Natural resources, } \\
\text { foreign } \\
\text { aid }\end{array}$ & & Regional \\
\hline Italy & $\begin{array}{l}\text { 'Organised crime' } \\
\text { groups } \\
\text { originating in southern } \\
\text { Italy }\end{array}$ & $\begin{array}{l}\text { Drugs, extortion, } \\
\text { counterfeit } \\
\text { merchandise, } \\
\text { state contracts }\end{array}$ & $\begin{array}{l}\text { Political, judicial, some } \\
\text { media, police }\end{array}$ & $\begin{array}{l}\text { Regional control and } \\
\text { penetration of national } \\
\text { institutions }\end{array}$ \\
\hline Kosovo & $\begin{array}{l}\text { Organised crime with } \\
\text { the participation of } \\
\text { some } \\
\text { KLA members }\end{array}$ & $\begin{array}{l}\text { Trafficking (weapons, } \\
\text { women, heroin) }\end{array}$ & $\begin{array}{l}\text { Institutions that might } \\
\text { impinge on or facilitate } \\
\text { trafficking }\end{array}$ & National \\
\hline
\end{tabular}

\footnotetext{
${ }^{45}$ Kupferschmidt. Loc. Cit.
} 


\begin{tabular}{|l|l|l|l|l|}
\hline $\begin{array}{l}\text { Country/ } \\
\text { region }\end{array}$ & $\begin{array}{l}\text { Alleged agent(s) of } \\
\text { state capture }\end{array}$ & $\begin{array}{l}\text { Primacy source(s) of } \\
\text { illicit political finance }\end{array}$ & $\begin{array}{l}\text { Primary institutional } \\
\text { targets }\end{array}$ & $\begin{array}{l}\text { Territorial expression } \\
\text { of state capture }\end{array}$ \\
\hline Pakistan & $\begin{array}{l}\text { Inter-Services } \\
\text { Intelligence (ISI) }\end{array}$ & Heroin, guns, the state & All institutions & National \\
\hline $\begin{array}{l}\text { Peru } \\
1990-2000\end{array}$ & $\begin{array}{l}\text { Vladimiro Lenin } \\
\text { Montesinos, Head of } \\
\text { Peru's Intelligence } \\
\text { Service }\end{array}$ & $\begin{array}{l}\text { Cocaine, weapons, } \\
\text { embezzlement, } \\
\text { procurement }\end{array}$ & $\begin{array}{l}\text { Tax authority, judiciary, } \\
\text { military, military } \\
\text { intelligence, media }\end{array}$ & National \\
\hline $\begin{array}{l}\text { Russia and } \\
\text { FSU }\end{array}$ & $\begin{array}{l}\text { 'Oligarchs' colluding } \\
\text { with } \\
\text { high state officials, } \\
\text { many } \\
\text { of whom came from the } \\
\text { security services }\end{array}$ & $\begin{array}{l}\text { Opaquely-privatised } \\
\text { industries and natural } \\
\text { resources (oil, gas), } \\
\text { state } \\
\text { contracts, taxes }\end{array}$ & $\begin{array}{l}\text { Most economic, political, } \\
\text { judicial and security } \\
\text { organs, including political } \\
\text { parties and media }\end{array}$ & $\begin{array}{l}\text { Regional and } \\
\text { international, but in } \\
\text { flux as state seeks to }\end{array}$ \\
\hline United States & Corporations & Legal profits & $\begin{array}{l}\text { Agencies regulating } \\
\text { relevant industry }\end{array}$ & some oligarchs \\
\hline
\end{tabular}

\section{Strategy For Combating Corruption}

The standard advice for combating corruption has traditionally focused on measures to address administrative corruption by reforming public administration and public finance management. But with the increasing recognition that the roots of corruption extend far beyond weaknesses in the capacity of government, the repertoire has been gradually expanding to target broader structural relationships, including the internal organisation of the political system, relationships among core state institutions, the interactions between the state and firms, and the relationship between the state and civil society. ${ }^{46}$

\section{Increasing political accountability:}

As political accountability increases, the costs to politicians of making decisions that benefit their private interests at the expense of the broader public interest also increase. Two of the key instruments for strengthening political accountability are: (i) increasing the transparency of decisions made by public officials and (ii) increasing competition through organisations that provide broad constituencies with vehicles, such as mass-based political parties, for expressing their collective demands.

\section{Strengthening institutional restraints within the state:}

The institutional design of the state can be an important mechanism in checking corruption, particularly, the effective separation of powers among state entities with each operating as a check on the abuse of power by the others. Strengthening and raising the credibility of the judicial system by enhancing the independence and accountability of judges and matching functions with budget and capacity are particularly important.

${ }^{46}$ The World Bank (2000). Anticorruption in Transition A Contribution to the Policy Debate from http://info.worldbank.org/etools/docs/library/17506/contribution.pdf 


\section{Strengthening civil society participation:}

As stakeholders in the quality of governance and as intermediaries for communication between the populace and the institutions of state, the organisations that comprise civil society can be essential in constraining corruption. Recently, there has been an emergence of greater civil society activism regarding corruption throughout the region, focused especially on: creating public awareness about corruption and the need to control it, formulating action plans to fight corruption, and monitoring government behaviour.

\section{Fostering an independent media:}

Free and open media help check the level of corruption by uncovering and shedding light on abuses. Yet the promise of a free press has not yet been fully realised in many transition countries. A policy of openness, formalised in laws guaranteeing free access to information, strengthens tools for oversight and enlists the media as an ally in controlling corruption.

\section{Creating a competitive private sector:}

A state is most vulnerable to capture when economic power is concentrated in a few firms or industries and when competing economic interests lack viable access to the policymaking process. The ability of powerful economic interests to capture the state can be checked by reducing the benefits to these firms from capture. This can be achieved in part by deepening price and trade liberalisation, increasing transparency in the ownership structure and operations of firms, and introducing greater competition in concentrated sectors by lowering barriers to entry and requiring competitive restructuring.

\section{Reforming public sector management:}

While strengthening mechanisms of external accountability is important, it is also essential to strengthen the internal management of public resources and administration to reduce opportunities and incentives for corruption. This requires instilling meritocracy and adequate pay in public administration.

In combating corruption an anti-corruption strategy is needed:

\section{Credible political leadership:}

A serious anticorruption program cannot be imposed from the outside, but requires committed leadership from within, ideally from the highest levels of the state.

Diagnosing the nature and extent of the problem in each case:

Implementing surveys, running workshops, and developing a dialogue with institutions of civil society on corruption are all critical for gaining countryspecific knowledge beyond the narrow limits of the typology. 
Assessing the environment:

The relevance and feasibility of specific reform instruments is closely linked to the way in which power is exercised, the level of informality in the society, and the extent to which people feel trust in their institutions and in each other.

\section{Finding appropriate entry points:}

It is critical to begin at a point where the goals are feasible and tangible results can be realised within a time frame that builds support for further reforms.

\section{Maximising leverage:}

Efforts should be made to design "win-win" anticorruption strategies that promote the interests and reputations of major politicians and businesspeople while delivering positive externalities such as enhancing economic growth, strengthening governance, or reducing poverty and inequality.

Based on some researches by the European Bank for Reconstruction and Development (EBRD) there is no close correlation between changes in levels of capture and the introduction of high-profile anti-corruption programmes. The same can be said for administrative corruption. However, anti-corruption programmes may take a while to have an impact and time series and overall number of observations in the transition region can be too limited to reach any firm conclusion. ${ }^{47}$

While the paradigm presented by Hellman and Kaufmann---of the actions of individuals, groups, or firms both in the public and private sectors to influence the formation of laws, regulations, decrees, and other government policies to their own advantage as a result of the illicit and non-transparent provision of private benefits to public officials---certainly has validity in defining the behaviour of political/economic actors in many countries of the world, it does require a degree of refinement if it is to be applied to the entire Former Soviet Union (FSU) region.

While there exists rampant corruption in the countries of the FSU and oligarchs in many countries have seized the lion's shares of State assets, the question arises as to who is capturing who. Is it a case of the State being captured by the private sector or a fusion of the State and the private sector? Putin already put it in quite a definite statement, "I only want to draw your attention straightaway to the fact that you have yourselves formed this very state, to a large extent through political and quasi-political structures under your control. So perhaps what one should do least of all is blame the mirror." 48

For Indonesia, the data released by TII is very intriguing: ${ }^{49}$

\section{Decrease in state support to political parties}

In 75 per cent of all liberal democracies in the world, the state provides financial assistance to political parties, with no significant differences between

${ }^{47}$ Bowser. Loc. Cit.

${ }^{48}$ Vladimir Putin, in a meeting with Russia's business leaders in July 2000 (Hoffman, 2000). from http://www.imf.org/external/pubs/ft/fandd/2001/09/hellman.htm

${ }^{49}$ TII. Loc. Cit. 
old and new democracies. India, Switzerland, New Zealand and the United States are the only liberal democracies which do not allocate public funds for political parties. However, even in some of these countries, state support is available for individual candidates.

\section{Increasing electoral costs}

Before 2004, political parties had to finance only one parliamentary campaign every five years, with executive officials elected afterwards by their respective legislatures. After the post-2004 reforms, which introduced direct elections for the presidency, governorships, and district head positions, the number of popular ballots in any one district in a five-year cycle rose to a minimum of four and a maximum of seven.

\section{Impact on state budgets: development of 'indirect state subsidies}

Following the implementation of the regulation in 2005, the share of per diems and other allowances in public budgets skyrocketed, with an increase of more than 80per cent for Parliament Members.

\section{Surge in political corruption}

150 gents and mayors and 17 governors have been jailed since 2005 .

Capture of political parties' leadership by wealthy candidates : disruption of leadership and weakening of political lines of demarcations

In the 2005 local elections, party affiliation has played only a very marginal role in the nomination process. Although parties had the exclusive right to nominate candidates, with independents barred from running, only 22 per cent of all nominees were party officials. The large majority was bureaucrats and entrepreneurs, with 36 and 28 per cent representation, respectively; 39.8 per cent of all members of the 2004-2009 national parliaments were businesspeople.

\section{Conclusion}

Power corrupts absolutely. To address Lord Acton (1952) after a century seems fit to this matter. "It is easier to find people fit to govern themselves than people to govern others. Every man is the best, the most responsible, judge of his own advantage."50

Illicit aspects of governance may appear difficult to assess, as they are by nature clandestine. However, this dark side of public life is not unknowable, and various scholars, particularly economists, are making inroads into describing and measuring these phenomena. The World Bank and others are currently attempting to analyse the conditions and processes by which state capture occurs, and to measure its extent.

Kaufmann whowas the first to research about state capture already explained that in some developing countries such as Indonesiathis type of corruption may not be referred to as state capture. Nonetheless the significant parties in the country that are involved in these matters already address the

${ }^{50}$ Lord Acton, as quoted by Himmelfarb in her work, Lord Acton, 1952 (University of Chicago Press, 1960) pp 172-3. from http://blupete.com/Literature/Biographies/Philosophy/Acton.htm 
issue. Indonesia Corruption Watch (ICW) and Transparency International Indonesia (TII) are some of them.

In analysing political financing regulations, TII addresses that such practices could actually be prevented to a larger extent if political parties were required to provide standardised financial reports in facilitating the audit of public accountants. This can go in three ways, as follows: first, by amending the law on general elections to challenge the Constitutional Court's decision; second, by limiting the donations of party members; and last, by revising the law on political parties to generalise reporting obligations in terms of corporate and individual donations outside the campaign period.

This writing is merely a contribution to the research at large. Due to the global form of corruption, every means is necessary. Hopefully, this piece can shed some light into the growing policy dialogue on developing practical strategies for reducing corruption. As more and more countries seek to implement anticorruption programs, it is critical for the other institutions to continue to enhance this dialogue with both the lessons of experience and the new approaches designed to tackle the roots of corruption.

\section{Bibliography}

Anders Aslund (2005). Comparative Oligarchy: Russia, Ukraine and the United

States. Center for Social and Economic Research from http://www.case.com.pl/ upload/publikacja_plik/4931074_SA\%20296last.pdf

Andrea Woodhouse (2005). Village Corruption in Indonesia Fighting Corruption in Indonesia's Kecamatan Development Program. Indonesian Social Development Paper No. 6

Anne Lugon-Moulin, Understanding State Capture. Freedom from Fear Magazine from http://www.freedomfromfearmagazine.org/index. php?option=com_content $\&$ view=article\&id=233:understanding-statecapture\&catid=49:issue-6\&Itemid=161

Antikorupsi.org. ICW Ajukan Sengketa Informasi soal Rekening Gendut Pati Polri (ICW asked for police account transparency) from http://antikorupsi. org/antikorupsi/?q=content/18862/icw-ajukan-sengketa-informasisoal-rekening-gendut-pati-polri

Antaranews.com. Todung: Kasus Lapindo adalah "state capture corruption (2009). Antaranews.com from http://www.antaranews.com/ berita/1251382626/todung-kasus-lapindo-adalah-state-capturecorruption

Antaranews.com. Calon Menteri harus tanda tangani komitmen antikorupsi (2009). Antaranews.com from http://www.antaranews.com/ berita/1255836656/calon-menteri-tanda-tangan-anti-korupsi

BEEPS. http://www.ebrd.com/pages/research/analysis/surveys/beeps.shtml

Center on International Cooperation (2011). Seminar on Organized Crime and State Capture, Meeting Report. New York University from http://www. cic.nyu.edu/peacebuilding/docs/Lima\%20Seminar\%20Background\%2 0Paper.pdf 
Daniel Kaufmann (2010), Breaking the Cycle of Crime and Corruption? Brookings from http://www.brookings.edu/opinions/2010/0414_corruption_ crime_kaufmann.aspx

Daniel Suryadarma (2008). Corruption, Public Spending, and Education Outcomes: Evidence from Indonesia Research School of Social Sciences The Australian National University.

David Kupferschmidt (2009). Illicit Political Finance and State Capture. International IDEA from http://www.idea.int/resources/analysis/ upload/IDEA_Inlaga_low.pdf

Donals Bowser. Addressing State Capture in Russia/Ukraine/Central Asia. Anti-Corruption Resource Center from http://www.u4.no/helpdesk/ helpdesk/queries/query18.cfm

Edgardo Buscaglia and Jan van Dijk (2003). Controlling Organized Crime and Corruption in the Public Sector. Forum on Crime and Society Vol 3 No. 1 and 2 from http://www.unodc.org/pdf/crime/forum/forum3_Art1.pdf

Joel Hellman and Daniel Kaufmann (2001). Confronting the Challenge of State Capture in Transition Economies, Finance \& Development. Volume 38 Number 3 from http://www.imf.org/external/pubs/ft/fandd/2001/09/ hellman.htm

J. Vernon Henderson and Ari Kuncoro (2004). Corruption in Indonesia. Brown University from http://www.pstc.brown.edu/henderson-kuncoro.pdf

Lily Evelina Sitorus (2009). Release and Discharge sebagai Altenatif Penyelesaian Masalah (Studi Banding Kasus Kebijakan Penyelesaian BLBI). Tesis: FISIP UI.

Lord Acton, as quoted by Himmelfarb in her work, Lord Acton, 1952 (University of Chicago Press, 1960) pp 172-3. from http://blupete.com/Literature/ Biographies/Philosophy/Acton.htm

Marie Chene (2009). Corruption Challenges at Sub-National Level in Indonesia. Anti-Corruption Resources Center from http://www.u4.no/helpdesk/ helpdesk/query.cfm?id=210

Taufik Rinaldi, Marini Purnomo and Dewi Damayanti (2007). Fighting Corruption in Decentralized Indonesia Case Studies on Handling Local Government Corruption from http://siteresources.worldbank.org/INTINDONESIA/ Resources/Publication/corruption_exec_sum_en.pdf

The World Bank (2000). Anticorruption in Transition A Contribution to the Policy Debate from http://info.worldbank.org/etools/docs/library/17506/ contribution.pdf

TII.MoneyPoliticsandStateCapture(2010).TransparencyInternationalIndonesia from http://www.ti.or.id/en/index.php/press-release/2010/11/11/ money-politics-and-state-capture

TIR. How to root out Russian corruption (2003). Transparency International Russia from http://www.transparency.org.ru/CENTER/c_public170403. asp

Vesna Pesic (2007). State Capture and Widespread Corruption in Serbia. CEPS Working Document No. 262/March 2007 from http://www.ceps.eu/ ceps/download/1309 
$\sim 68 \sim$

Vladimir Putin, in a meeting with Russia's business leaders in July 2000 (Hoffman, 2000). from http://www.imf.org/external/pubs/ft/fandd/2001/09/ hellman.htm

UU No 14 Tahun 2008 (Law Number 14 Year 2008). 